\title{
Urban mobility, socioeconomic and urban transport variables in metropolitan areas in three continents
}

\author{
Fabiene Cristina de Carvalho da Costa \\ COPPE/ Federal University of Rio de Janeiro, Brazil \\ Carlos David Nassi \\ COPPE/ Federal University of Rio de Janeiro, Brazil
}

\section{SUMMARY}

Transportation is the soul of urban cities. Find sustainable ways to keep people moving in our cities is more important than ever. Historically, cities have developed in different ways. Each has its own personality and complexity. But in all cases, transport and mobility have played a key role in city life. Due to the relevance of mobility this article tries to establish the relationship between some variables. The method was developed by collecting, analyzing and comparing data on metropolitan regions in North America, South America, Europe and Oceania through a mathematical model. From each selected location the following data were gathered: population, area $\left(\mathrm{km}^{2}\right)$, demographic density (inhab $\left./ \mathrm{km}^{2}\right)$, socio-economic aspects (annual GDP per capita), transport system (subway extension), number of trips per person per day and modal split (\% non-motorized, \% public transport and \% private transport). In this study we analyze some variables that influence the number of trips per person per day. Understanding the associations between all the variables that influence the number of trips per person per day contributes the planners to determine whether changes are needed to improve in the transport system in the metropolitan region.

Keywords: urban transport; mobility; transport planning

\section{INTRODUCTION}

According to the United Nations (2013) "Most of the urban growth in the world occurs in developing countries where many urban centers already have inadequate infrastructure and authorities are looking for solutions to respond adequately to the demands of the rapid expansion of urban populations, especially youth and poor".

It further states that half the world's population lives in urban areas, with a third of these are in slums and informal settlements. The number of people living in slums rose from 760 million in 2000 to 863 million in 2012. Estimates indicate that by the year 2050, over $70 \%$ of the world population will live in urban cities.

Find sustainable ways to manage all type of infrastructure (water, sanitation, health facilities, housing, public transport, road network, etc.) is extremely important for the life quality of its citizens.

Historically, cities have developed in different ways. Each one has its own sociocultural characteristics and complexity. But in all cases, transport and mobility have played a key 
role in city life.

Transportation is the lifeblood of cities. The city configuration and the transport system determine most of origin-destination trips. The residential, business and industrial areas, the coverage and quality of the public transport system, the fare system, the motorized accessibility, and other aspects influence the urban mobility. Above we present a concise literature review about variables that influences the mobility.

Albalate and Bel (2010) study analyzes factors explaining supply and demand of local public transportation in 45 European cities. Together with variables related to traditional economic factors and mobility, they consider variables reflecting institutional characteristics and geographical patterns. They find that GDP produces positive impacts on the supply side of local public transportation across the 45 European cities. Therefore, being richer implies higher number of place-km per inhabitant than relatively poorer cities. The other variables, including the average price of a passenger-km and urban population density, do not present statistically significant coefficients. At the same time, urban population density was thought to affect supply through its impacts on economic efficiency, but its coefficient does not seem statistically significant at all. It is possible that urban population density is not able to capture urban form by itself.

Stead and Marshall (2001) present in their work that according to ECOTEC (1993), total journey frequency does not show a clear gradation with population density and there is little variation in trip frequency according to population density.

According to TDA Inc. (2001) as population density increases the mode of travel for persons varies. It increases the number of trips by bike/walk and reduces the number of trips by car.

US Department of Transportation (2013) reports that higher-density areas can provide more opportunities for walking, biking, and transit use than lower-density areas. In some lowdensity neighborhoods, transit services are not cost-effective to provide and there are few destinations, such as schools, jobs, or shopping, within walking distance. People may be left with no other choice but to drive. Households living in higher-density areas have more transportation choices. Of the 50 Metropolitan Statistical Areas (MSAs) with population greater than 1 million, 14 have at least 10 percent of their population living in high-density block groups of 10,000 or more persons per square mile.

According to Litman (2015a) the land use factor population density affects the travel behavior as reduces vehicle ownership and travel, and increases use of alternative modes. A $10 \%$ increase typically reduces VMT (vehicle miles of travel) $0.5-1 \%$ as an isolated factor, and $1-4 \%$ including associated factors (regional accessibility, mix, etc.).

O`Flaherty (2006) says that transport plans which emphasize land use planning and the 
intricacies of individual site design recognize that control of land use is to a large extent the key to the control of both the demand for transport and its impact upon the environment.

According of Committee on National Statistics (2002), the most frequently cited mobility measures fall into six major areas: congestion related (e.g., level of service, volume/capacity, and delay); trip time; amount of travel (vehicle miles traveled, vehicle hours traveled); mode share; transfer time; and transit performance.

For Newman and Kenworthy (2011) the relationship between density and car use is exponential. If a city begins to slowly increase its density then the impact can be more extensive on car use than expected. Density is a multiplier on the use of transit and walking/cycling, as well as reducing the length of travel.

It is important to emphasize that according to Newman and Kenworthy (2011) there was a peak car use and so there was a change in the modal split in the cities between 1995 and 2005 .

This article tries to obtain a relationship between the urban mobility and some aspects in a metropolitan region. The objective is to analyze the relationship between Population, area $\left(\mathrm{km}^{2}\right)$, Demographic density (inhab/ $\mathrm{km}^{2}$ ), Annual GDP per capita (US\$), Subway extension $(\mathrm{km})$ and modal split (\% non-motorized, \% public transport and \% private transport) with Trips per person per day (indicator selected to represent urban mobility) in different metropolitan regions around the world.

\section{METHODOLOGY}

\subsection{Choice of metropolitan areas}

There are a lot of studies that uses cities instead of metropolitan areas as the important sourcebook about cities and car dependence by Newman and Kenworthy (1989). The metropolitan areas include multiple jurisdictions and municipalities. A typical metropolitan area is centered on a single large city that wields substantial influence over the region. However, some metropolitan areas contain more than one large city with no single municipality holding a substantially dominant position. This study tries to analyze mobility in different metropolitan regions in three continents.

The choice of metropolitan areas is related to the geographic localization and available data for each aspect analyzed for each metropolitan area.

\subsection{The data}

Peter Newman, Jeffrey Kenworthy and Felix Laube have been working for several years collecting and analyzing data related to transportation efficiency, key economic and environmental variables from different cities around the world. On the other hand this study 
provides an insight in some aspects related to transportation in metropolitan regions.

We analyzed 29 metropolitan regions, 15 (fifteen) from Europe, 6 (six) from North America, 6 (six) from South America and 2 (two) from Oceania. The characteristics analyzed were: Population, area $\left(\mathrm{km}^{2}\right)$, Demographic density (inhab $/ \mathrm{km}^{2}$ ), Annual GDP per capita (US\$), Subway extension $(\mathrm{km})$, Trips per person per day and modal split (\% non-motorized, \% public transport and \% private transport) (table 1). It is important to mention that the number of trips per person per day includes all types of trips made in the metropolitan region including walking for different purposes. The Modal Split presented is for all trips made in the region and the non-motorized variable includes walking and cycling.

Most of the data were obtained from Toronto as a Global City: Scorecard on Prosperity 2012 and EMTA Barometer of Public Transport in European Metropolitan Areas (2012). It is important to mention the attempting to use data from the same report to minimize different types of standardization of the metropolitan areas (criteria to determine each area). Regarding the South America metropolitan areas, data were collected from the respective official Argentinian and Brazilian websites of the government and transport sectors. 


\begin{tabular}{|c|c|c|c|c|c|c|c|c|c|}
\hline Metropolitan area & $\begin{array}{c}\text { Population } \\
\text { (inhabitants) }\end{array}$ & $\begin{array}{l}\text { Area } \\
\left(\mathrm{km}^{2}\right)\end{array}$ & $\begin{array}{l}\text { Population } \\
\text { density } \\
\left(\text { inhab } / \mathrm{km}^{2}\right)\end{array}$ & $\begin{array}{l}\text { Annual } \\
\text { GDP per } \\
\text { capita } \\
\text { (US\$) }\end{array}$ & $\begin{array}{c}\text { Subway } \\
\text { extension } \\
(\mathrm{km})\end{array}$ & $\begin{array}{l}\text { Trips } \\
\text { per } \\
\text { person } \\
\text { per day }\end{array}$ & $\begin{array}{c}\% \text { non- } \\
\text { motorized }\end{array}$ & $\begin{array}{c}\% \\
\text { public } \\
\text { transport }\end{array}$ & $\begin{array}{c}\% \\
\text { private } \\
\text { transport }\end{array}$ \\
\hline Amsterdam (Netherlands) & $1,406,500$ & $1,003.5$ & 1,402 & $38,704.0$ & 120.0 & 2.6 & 54.0 & 10.0 & 36.0 \\
\hline Barcelona (Spain) & $5,345,603$ & $7,716.9$ & 693 & $33,769.0$ & 102.6 & 3.7 & 49.1 & 18.9 & 32.0 \\
\hline $\begin{array}{l}\text { Berlin-Brandenburg } \\
\text { (Germany) }\end{array}$ & $5,954,000$ & $30,372.0$ & 196 & $31,000.3$ & 146.0 & 3.3 & 39.0 & 16.0 & 45.0 \\
\hline Belo Horizonte (Brazil) & $5,414,701$ & $14,420.3$ & 375 & $15,673.0$ & 28.2 & 2.4 & 40.2 & 27.5 & 32.3 \\
\hline Brussels (Belgium) & $3,100,000$ & $5,000.0$ & 620 & $81,229.7$ & 39.9 & 2.4 & 30.6 & 15.3 & 54.2 \\
\hline Budapest (Hungary) & $2,951,000$ & $7,586.1$ & 389 & $20,754.0$ & 38.2 & 3.0 & 24,8 & 37.4 & 37.8 \\
\hline Buenos Aires (Argentina) & $12,985,885$ & $2,990.1$ & 4,342 & $36,911.0$ & 52.0 & 1.5 & 8.6 & 40.4 & 51.0 \\
\hline Calgary (Canada) & $1,242,624$ & $5,107.5$ & 243 & $61,246.0$ & 0 & 3.6 & 6.6 & 16.4 & 77.0 \\
\hline Chicago (United States) & $9,622,245$ & $18,904.2$ & 509 & $46,754.0$ & 165.0 & 2.6 & 20.0 & 17.0 & 63.0 \\
\hline Córdoba (Argentina) & $1,581,113$ & 720.0 & 2,195 & $9,097.0$ & 0 & 1.8 & 30.0 & 38.9 & 31.1 \\
\hline Helsinki (Finland) & $1,033,933$ & 791.0 & 1,307 & $69,965.8$ & 21.1 & 3.1 & 34.0 & 38.8 & 27.2 \\
\hline Lille (France) & $1,093,000$ & $1,453.1$ & 752 & $25,195.0$ & 45.0 & 3.8 & 33.0 & 10.0 & 57.0 \\
\hline London (England) & $7,753,600$ & $1,579.0$ & 4,910 & $45,273.4$ & 402.0 & 2.4 & 22.5 & 44.3 & 33.3 \\
\hline Lyon (France) & $1,285,942$ & 515.0 & 2,497 & $36,209.8$ & 32.0 & 3.4 & 35.3 & 16.3 & 48.6 \\
\hline Madrid (Spain) & $6,295,011$ & $8,026.0$ & 784 & $34,939.0$ & 293.0 & 2.6 & 31.2 & 31.6 & 37.2 \\
\hline Melbourne (Australia) & $4,250,000$ & $8,097.2$ & 443 & $37,100.0$ & 0 & 3.2 & 6.0 & 17.0 & 77.0 \\
\hline Montreal (Canada) & $3,859,318$ & $4,258.3$ & 906 & $24,785.0$ & 71.0 & 2.0 & 13.0 & 18.0 & 69.0 \\
\hline New York (United States) & $19,151,072$ & $17,405.0$ & 1,100 & $55,671.0$ & 396.0 & 4.1 & 18.0 & 15.0 & 67.0 \\
\hline Paris (France) & $11,672,500$ & $11,863.5$ & 983 & $60,214.2$ & 219.0 & 3.8 & 40.3 & 20.2 & 39.5 \\
\hline Rio de Janeiro (Brazil) & $11,835,708$ & $5,643.8$ & 2,097 & $13,656.0$ & 41.0 & 1.9 & 31.8 & 48.8 & 19.5 \\
\hline
\end{tabular}




\begin{tabular}{|l|r|r|r|r|r|c|c|c|c|}
\hline Metropolitan area & $\begin{array}{c}\text { Population } \\
\text { (inhabitants) }\end{array}$ & $\begin{array}{c}\text { Area } \\
\left(\mathrm{km}^{2}\right)\end{array}$ & $\begin{array}{c}\text { Population } \\
\text { density } \\
\left(\mathrm{inhab} / \mathrm{km}^{2}\right)\end{array}$ & $\begin{array}{c}\text { Annual } \\
\text { GDP per } \\
\text { capita } \\
(\mathrm{US} \$)\end{array}$ & $\begin{array}{c}\text { Subway } \\
\text { extension } \\
(\mathrm{km})\end{array}$ & $\begin{array}{c}\text { Trips } \\
\text { per } \\
\text { person } \\
\text { per day }\end{array}$ & $\begin{array}{c}\% \text { non- } \\
\text { motorized }\end{array}$ & $\begin{array}{c}\% \\
\text { public } \\
\text { transport }\end{array}$ & $\begin{array}{c}\% \\
\text { private } \\
\text { transport }\end{array}$ \\
\hline Rosário (Argentina) & $1,305,380$ & 589.0 & 2,216 & $13,008.0$ & 0 & 1.5 & 21.0 & 30.5 & 48.5 \\
\hline São Paulo (Brazil) & $20,012,000$ & $8,072.6$ & 2,479 & $21,650.0$ & 78.3 & 2.2 & 31.9 & 36.9 & 31.2 \\
\hline Seville (Spain) & $1,442,734$ & $4,219.2$ & 342 & $13,724.5$ & 18.0 & 2.4 & 33.0 & 14.0 & 53.0 \\
\hline Stockholm (Sweden) & $1,981,263$ & $7,106.9$ & 278 & $48,364.4$ & 108.0 & 3.0 & 31.0 & 25.0 & 44.0 \\
\hline Sydney (Australia) & $4,575,500$ & $12,367.7$ & 369 & $33,169.0$ & 0 & 4.4 & 18.6 & 12.4 & 69.0 \\
\hline Toronto (Canada) & $5,741,419$ & $5,905.7$ & 972 & $34,228.0$ & 68.3 & 3.0 & 6.0 & 16.0 & 78.0 \\
\hline Turin (Italy) & $1,555,778$ & 837.0 & 1,859 & $26,632.7$ & 13.2 & 2.3 & 27.6 & 19.2 & 53.2 \\
\hline Vancouver (Canada) & $2,391,252$ & $2,979.7$ & 802 & $28,223.0$ & 68.3 & 2.5 & 13.0 & 14.0 & 73.0 \\
\hline Warsaw (Poland) & $2,401,000$ & $2,277.9$ & 1,054 & $16,908.2$ & 29.0 & 1.8 & 32.5 & 30.2 & 37.3 \\
\hline
\end{tabular}

Table 1 - Characteristics of the metropolitan areas selected. 


\section{ANALYSES}

\subsection{Variables}

We analyzed 29 metropolitan regions the data, related to the average GDP per capita, Europe is 2.1 times higher, North America is 2.3 times higher and Oceania is 1.9 higher than South America. In relation to the subway extension, Europe is 3.3 times higher and North America is 3.8 times higher than South America. With these data we cannot confirm that comparing population density and subway extension, in general, as higher is the population density, greater is the subway network. In relation to the number of trips per person per day Europe and North America are almost equal with rounded 1.5 times higher and Oceania 2.0 higher than South America. In relation to the modal split, South America uses more non-motorized vehicles than Oceania and North America, loses only for Europe (1.26 times higher). Public Transport are more used utilized in average in South America, 1.6 higher than Europe, 2.3 higher than North America and 2.5 higher than Oceania. The \% of private transport is the highest in Oceania (73\%) but there were analyzed only 2 (two) metropolitan regions. The North America is the second one with $71.1 \%, 42.3 \%$ in Europe and $35.6 \%$ in South America.

To select which variable is going to be analyzed in the mathematical model we used the SPSS (Stepwise command) that indicated the variables that influence directly with the independent one and present measures that are validated in the verification of statistical significance.

Then with the indication of SPSS analyses were made the mathematical model presented in item 3.2.

\subsection{Mathematical Model}

In relation to the Mathematical Model, we utilized multiple linear regression to determine a mathematical model to provide the number of trips per person (tpp) per day for each urban region under analysis.

Multiple linear regression:

$\mathrm{y}_{\mathrm{i}}=\mathrm{a}+\mathrm{b}_{1} \mathrm{X}_{1}+\mathrm{b}_{2} \mathrm{X}_{2}+\ldots+\mathrm{b}_{\mathrm{n}} \mathrm{X}_{\mathrm{n}}$

Where:

$\mathrm{y}_{\mathrm{i}}=$ number of trips per day

$\mathrm{X}_{\mathrm{k}}=$ variables chosen as determinants

The results presented in the regression are acceptable. The two variables analyzed present important signification: Annual GDP per capita $\left(\mathrm{X}_{1}\right)$ and modal split with the \%public transport $\left(\mathrm{X}_{2}\right)$. 
When analyzing them the value of $\mathrm{R}^{2}$ corresponds to $40 \%$ of the association between the dependent variable (y) and the two independent variables, and there is a suitable t-statistics for the variables $\mathrm{X}_{1}$ and $\mathrm{X}_{2}$.

The following equation is obtained:

$$
\begin{gathered}
\text { tpp }=3.0549+0.000014 * \text { Annual GDP per capita }-0.0327 * \% \text { pulic transport }(1) \\
\mathrm{t}=2.12 \quad \mathrm{t}=-3.05
\end{gathered}
$$

The signs presented in the coefficients demonstrate the higher the income (GDP per capita) higher is the number of trips per person per day. In relation to \% public transport we notice that the negative sign can indicate that as the use of public transport increase the number of trips decreases, there are some hypotheses about it:

1) The user, in general, spent more time in the trip at the public transport, consequently there is less time to make more trips or the user don't have more energy to make more trips.

2) As higher is the income less is the use of public transport.

3) As higher is the income, more money can be spent on trips.

In the metropolitan area of Rio de Janeiro, for example, the average time spent on homework trip is 50min and the number of trips per person per day is 1.9. On the other hand Paris metropolitan area (Ile de France) that has almost the same population quantity, the average time spent on the home-work trip is $33.7 \mathrm{~min}$ and the number of trips per person per day is 3.8 .

Dargay (1999) study demonstrated in there analyses using historical data for more than three decades and 26 countries that exists a strong historical relationship between the growth of per-capita income and the growth of car and vehicle ownership. As per capita income grows, so will car and vehicle ownership and consequently less use of public transport.

According to Paulley et all (2006) income is expected to increase the number of trips and their average length. It is likely that this additional travel will be split between increased public transport trips and increased car trips, depending upon the level of car availability and assuming that public transport is a normal good. Income is also a key determinant of car ownership and hence there will be a secondary and negative impact on the demand for public transport via car ownership. There are other background factors that can be cited as key factors to shape personal travel patterns: An increase in income will, depending upon the level of income, lead to an increase in car ownership and so car availability, or to an increase in public transport use and an increase in car ownership/availability will, other things being equal, lead to a reduction in the demand for public transport modes. 
It is important to mention that due to the collinearity between car ownership (or in this case, $\%$ private transport) and public transport they are not used in the same model.

Litman (2015b) explains that transit is an important travel mode for low- and middle-income non-drivers. For example, a household earning \$20,000 annual income typically spends about $\$ 2,500$ (canadian dollars) per year on transport. On this budget, a non-driver in a community with no transit service can only afford about five taxi trips per week (resulting in an inferior level of mobility). A non-driver who lives in a community with good transit service can purchase a monthly transit pass and still afford two or three taxi trips per week, providing a relatively high level of mobility, although still inferior to a driver.

The literature review presented showed the influence of density in the urban mobility. However due to the data analyzed this variable didn't showed significant and satisfactory results.

It is interesting to mention that the literature tends to talk about good transit service, but what happens when the service is not good? Not good service, more time spent on the trip, less trips, more healthy problems...?

\section{CONCLUSIONS}

This study tries to analyze some variables that influence the number of trips per person per day. Understanding the associations between all the variables that influence the number of trips per person per day contributes the planners to determine whether changes are needed to improve the transport system in the metropolitan region and the population life quality. The data was only obtained from World Wide Web, with no funds or group workers, from different metropolitan regions around the world and their related socioeconomic and transportation characteristics.

Comparing all the data presented in table 1 and in section 3.1 we notice clearly the difference between metropolitan regions in developing countries and the ones in developed countries. The South America metropolitan areas that are in a developing country presents low levels in all variables analyzed, except for \% public transport. This can show that lower GDP per capita is related to higher use of public transport and lower use of private ones.

We found a multiple linear regression model that showed $40 \%$ association between the number of trips per person per day and the variables Annual GDP per capita and \%public transport use. The results presented in section 3.2 highlights the importance of the income in the urban mobility. Depending if it increases or decreases the number of trips per person 
changes and the $\%$ public transport use also contributes to that.

Even inside the same continent there is two different and opposite transportation interactions. One with elevated percentage of private transport and trips per person per day, and the other totally opposite with high public transit and low number of trips per person per day.

According to Newman and Kenworthy (2011) there was a peak car use and the possible causes are: Hitting the Marchetti wall (average time budget of around one hour), the growth of public transport, the reversal of urban sprawl, the ageing of cities, the growth of a culture of urbanism and rise in fuel prices. This statement shows that there are several aspects or characteristics that can influence in the urban mobility.

The quality of the public transport must be introduced in further studies. It is clear that in metropolitan regions in developed countries the quality of transport system influence the population mobility.

It is interesting to mention that as transportation is the lifeblood of cities, problems will always happen differently for each metropolitan region and each metropolitan transport sector will treat that according to their socio-economic characteristics, culture, land use and objective. It is very important the communication between the transportation specialists and the changing ideas. The only thing that is certain according to Litman (2015c) is that public transportation can provide significant health benefits. People who live or work in communities with high public transportation quality tend to own fewer vehicles, drive less, and utilize alternative modes more than they would in more automobile-oriented locations. This can provide large reductions in traffic crashes and pollution emissions, increases in physical fitness and mental health, and improved access to healthy food, housing and medical care. These health benefits are significant in magnitude compared with other planning objectives, but are often overlooked or undervalued in conventional transport planning.

\section{REFERENCES}

Albalate, D. and Bel, G. (2010). 'What shapes local public transportation in Europe? Economics, mobility, institutions, and geography' Transportation Research Part E 46, pp.775-790.

Committee on National Statistics (2002). Key Transportation Indicators: Summary of a Workshop (2002). National Research Council; Division of Behavioral and Social Sciences and Education.Washington, D.C.

Dargay, J. and Gately, D. (1999). 'Income`s effect on car vehicle ownership worldwide: 
1960-2015' Transportation Research Part A 33, pp.101-138.

ECOTEC (1993) Reducing transport emissions through land use planning. HMSO, London.

EMTA. Barometer of public transport in European Metropolitan Areas. European Metropolitan Transport Authorities (2012).

EUROSTAT. Database available at: http://ec.europa.eu/eurostat/data/database

Litman, T. (2015a). 'Land Use Impacts on Transport. How Land Use Factors Affect Travel Behavior' Victoria Transport Policy Institute with Rowan Steele.

Litman, T. (2015b) Evaluating Public Transit Benefits and Costs. Best Practice Guidebook. Victoria Transport Policy.

Litman, T. (2015c). 'Evaluating Public Transport Health Benefits'Victoria Transport Policy Institute.

Newman, P. and Kenworthy, J.R. (1989). Cities and Automobile Dependence: A Sourcebook. Gower Publishing Company.

Newman, P and Kenworthy, J.R. (1999). 'Patterns of automobile dependence in cities: an international overview of key physical and economic dimensions with some implications for urban policy' Transportation Research Part A 33, pp.691-723.

Newman, P and Kenworthy, J.R. (2011). “Peak Car Use': Understanding the demise of automobile dependence'World Transport Policy and Practice volume 17.

O`FLAHERTY, C.A. (2006). Transport Planning and Traffic Engineering. Elsevier.

Paulley, N.; Balcombe, R.; Mackett, R.; Titheridge, H.; Preston, J.; Wardman, M.; Shires, J. and White, P.(2006). 'The demand for public transport: The effects of fares, quality of service, income and car ownership' Transport Policy volume 13 issue 4, pp.295-306.

TDA INC. (2001). The Land use transportation connection. NHTS (2001).

Toronto Board of Trade. Toronto as a global city: scorecard on prosperity -2012.

United Nations Population Fund (UNFPA), 2013. Available at:

$<$ http://www.onu.org.br/onu-mais-de-70-da-populacao-mundial-vivera-em-cidades-ate$2050 / />$.

US Department of Transportation (2013). Policy and Governmental Affairs. 2013 Status of the Nation's Highways, Bridges, and Transit: Conditions \& Performance. 